\title{
Selected Findings and Current Perspectives on Urban and Agricultural Water Quality by the National Water-Quality Assessment Program
}

\author{
Studies by the USGS National Water-Quality Assessment (NAWQA) program in the last decade describe water- \\ quality conditions in nearly 120 agricultural and 35 urban watersheds ("urban" primarily refers to residential \\ and commercial development over the last 50 years). The findings show that for both urban and agricultural \\ areas, nonpoint chemical contamination is an issue. Much work still needs to be done in urban areas with
} point source contamination as well, including infrastructure improvements. Appreciable improvements in overall water quality, however, will depend upon effective management of point and nonpoint sources. The findings also show that water-quality conditions and aquatic health reflect a complex combination of land and chemical use, land-management practices, population density and watershed development, and natural features, such as soils, geology, hydrology, and climate. Contaminant concentrations vary from season to season and from watershed to watershed. Even among seemingly similar land uses and sources of contamination, different areas can have very different degrees of vulnerability and, therefore, have different rates at which improved treatment or management can lead to water-quality improvements.

\section{Water Quality in Agricultural Watersheds}

- Nitrogen and phosphorus in surface water commonly exceed levels that contribute to excessive algae. For example, average annual concentrations of phosphorus in nearly 80 percent of streams sampled in agricultural areas were greater than the U. S. Environmental Protection Agency (USEPA) desired goal for preventing nuisance plant growth in streams. Excessive plant growth can lead to low dissolved oxygen, which can be harmful to fish and other aquatic life.

- Nitrate is often elevated above background levels in shallow ground water underlying farmland. Concentrations in about 20 percent of shallow wells sampled in agricultural areas exceeded the USEPA drinking water standard. This result is a concern in rural areas where shallow ground water is used for domestic supply; these domestic wells are not regulated and owners often do not know the quality of their well water or whether their wells are vulnerable to contamination. Nitrate is most often elevated in karst (carbonate) areas or where soils and aquifers consist of sand and gravel. These natural features enable rapid infiltration and downward movement of water and chemicals. Some of the more vulnerable areas are the Central Valley of California, and parts of the Pacific Northwest, the Great Plains, and the Mid-Atlantic region. In contrast, ground-water contaminants underlying farmland in parts of the upper Midwest are barely detectable, despite similar high rates of chemical use. In these areas groundwater contamination may be limited because of relatively impermeable, poorly drained soils and glacial till that cover much of the region, and because tile drains provide quick pathways for runoff to streams.
- Pesticides are widespread. At least one pesticide was detected in more than 95 percent of stream samples. Pesticides were detected in more than 60 percent of shallow wells sampled in agricultural areas.

- Pesticides commonly occur in mixtures. Two-thirds of stream samples collected in agricultural areas contained 5 or more pesticides, and more than one-quarter of the samples contained 10 or more. Ground water contained fewer pesticides; about 30 percent of the wells sampled contained 2 or more.

- Concentrations of pesticides generally are low and below drinking-water standards. However, the risk to humans and the environment from present-day low levels of contaminant exposure remains unclear. For example, current standards and guidelines do not yet account for exposure to mixtures, and many pesticides and their breakdown products do not have standards or guidelines.

- Herbicides-most commonly atrazine and its breakdown product desethylatrazine, and metolachlor, cyanazine, and alachlor-occur more frequently and usually at higher concentrations in agricultural streams and ground water than in urban waters. Their occurrence is linked to their use; they rank in the top five in national herbicide use for agriculture.

- Insecticides that were used in the past still persist in agricultural streams and sediment. DDT was the most commonly detected organochlorine compound, followed by dieldrin and chlordane. Their uses were restricted in the 1970s and 1980s and, yet, more than 20 years later, one or more sedimentquality guidelines were exceeded at more than 20 percent of agricultural sites. 


\section{Water Quality in Urban Watersheds}

- Concentrations of fecal coliform bacteria commonly exceed recommended standards for water-contact recreation.

- Concentrations of total phosphorus are generally as high in urban streams as in agricultural streams. More than 70 percent of sampled urban streams exceeded the USEPA desired goal for preventing nuisance plant growth.

- Insecticides, such as diazinon, carbaryl, chlorpyrifos, and malathion, occur more frequently, and usually at higher concentrations in urban streams than in agricultural streams. Concentrations are low in urban streams, rarely exceeding USEPA drinking-water standards. However, effects on aquatic life may be more of a concern. Concentrations of insecticides exceeded at least one guideline established to protect aquatic life in every sampled urban stream.

- Herbicides are widespread in surface water (detected in 99 percent of urban stream samples) and ground water (detected in more than 50 percent of sampled wells). Most common are those applied to lawns, golf courses, and road right-of-ways, such as atrazine, simazine, and prometon.

- Similar to agricultural areas, pesticides in urban waters commonly occur in mixtures; nearly 80 percent of stream samples contained 5 or more pesticides. Two of the most commonly detected insecticides in mixtures were diazinon and chlorpyrifos; common herbicides detected were simazine and prometon.

- Sediment in urban streams is associated with higher frequencies of occurrence of DDT, chlordane, and dieldrin and higher concentrations of chlordane and dieldrin than sediment in agricultural streams. Sediment-quality guidelines for organochlorine pesticides were exceeded at 36 percent of sampled urban sites.

- Volatile organic compounds, which are used in plastics, cleaning solvents, gasoline, and industrial operations, occur widely in shallow urban ground water. Some of the most frequently detected of the 60 analyzed compounds were the commercial and industrial solvents trichloroethene (TCE), tetrachloroethene (PCE), and methylene chloride; the gasoline additive methyl tert-butyl ether (MTBE); and the solvent and disinfection by-product of water treatment, trichloromethane (also known as chloroform).
- Concentrations of selected trace elements, such as cadmium, lead, zinc, and mercury, are elevated above background levels in populated urban settings, most likely caused by emissions from industrial and municipal activities and motor vehicles. Sediment cores from streambeds and reservoirs, which can be used to track changes over long time periods, indicate that lead increased from 1940s to the 1970s, and began to decrease after it was removed from gasoline. Concentrations are not yet down to background levels. Decreases also are noted for DDT and chlordane.

- In contrast to lead, DDT, and chlordane, sediment cores indicate that zinc and polycyclic aromatic hydrocarbons (PAHs, which result from fossil fuel combustion) are increasing. These increases most likely relate to increasing motor vehicle traffic in watersheds. Sediment-quality guidelines for PAHs were exceeded at more than 40 percent of urban sites.

- Toxic compounds in streambed sediment in urban areas, such as DDT, chlordane, dieldrin, and PCBs, also were found in fish tissue, often at higher concentrations than in the sediment. One or more organochlorine compounds were detected in 97 percent of whole fish samples collected at urban sites, and PCBs were detected in more than 80 percent of whole fish samples. Concentrations of organochlorine compounds exceeded guidelines to protect wildlife at more than 10 percent of urban sites; wildlife guidelines for PCBs were exceeded at nearly 70 percent of urban sites. These findings have contributed to decisions by some states to issue fishconsumption advisories.

- Deteriorated water quality and sediment, as well as habitat disturbances, contribute to degraded biological communities in urban streams. The greatest effects are seen in areas with the highest human population densities and watershed development. Pollution-tolerant algae and aquatic invertebrates (such as worms and midges), as well as omnivorous fish communities, prevail at the affected sites.

\section{Contacts for additional information or questions:}

Tim Miller (703) 648-6868 (tlmiller@usgs.gov)

Pixie Hamilton (804) 261-2602 (pahamilt@usgs.gov)

\section{For Internet access to NAWOA publications, data, and maps:}

